\title{
Self-Perception About The Competence Of Mechanical Engineering Education Students As Prospective Teachers
}

\section{Persepsi Dirı Tentang Kompetensi Mahasiswa Pendidikan Teknik Mesin Sebagai Calon Guru}

\author{
Ahmad Eko Suryanto ${ }^{(1)}$ Marko Ayaki Lumbantobing ${ }^{(2)}$ \\ 1), 2) Pendidikan Teknik Mesin, Fakultas Keguruan dan Ilmu Pendidikan Universitas Palangka Raya \\ Kampus UPR Tunjung Nyaho Jl. H. Timang, 73111A \\ e-mail: ahmadeko.s@fkip.upr.ac.id
}

\begin{abstract}
This study aims to describe the competencies possessed by mechanical engineering education students based on self-perception. These competencies are pedagogic competence, personality competence, sosial competence and professional competence. The results showed that students of the Mechanical Engineering Education Study Program (PTM), Palangka Raya University (UPR) had quite good pedagogical competence, good personality competence, good sosial competence and fairly good professional competence.
\end{abstract}

Keywords: competence, prospective teachers

\begin{abstract}
ABSTRAK
Penelitian ini bertujuan untuk mendeskripsikan kompetensi yang dimiliki oleh mahasiswa Pendidikan teknik mesin berdasarkan persepsi diri. Kompetensi tersebut adalah kompetensi pedagogic, kompetensi kepribadian, kompetensi sosial dan kompetensi professional. Hasil penelitian menunjukan bahwa mahasiswa Program Studi Pendidikan Teknik Mesin (PTM), Universitas Palangka Raya (UPR) memiliki kompetensi pedagogik yang cukup baik, kompetensi kepribadian yang baik, kompetensi soSial yang baik dan kompetensi professional yang cukup baik.

Kata kunci: kompetensi, calon guru.
\end{abstract}

\section{PENDAHULUAN}

Seorang guru wajib memiliki standar kompetensi yang berlaku secara nasional meliputi empat kompetensi utama yang terintegrasi dalam kinerja guru, yaitu kompetensi pedagogik, kopetensi kepribadian, kompetensi sosial dan kompetensi profesional. Kompetensi pedagogik adalah kompetensi yang wajib dikuasai oleh guru, karena kompetensi pedagogik merupakan salah satu kompetensi yang dapat mempengaruhi hasil belajar yang dicapai oleh peserta didik. Hal ini dibuktikan oleh Umami (2013, p.86), dalam penelitiannya menyatakan bahwa kompetensi pedagogik guru berpengaruh signifikan terhadap hasil belajar siswa.

Masalah utama yang dihadapi dunia pendidikan adalah rendahnya mutu dan kualitas guru di Indonesia. Kepala Badan Pengembangan Sumber Daya Manusia Pendidikan Kebudayaan (BPSDMPK) dan Peningkatan Mutu Pendidikan (PMP), Kementrian Pendidikan dan Kebudayaan (Kemdikbud), Syahwal Gultom dalam Seminar Mutu Pendidikan Nasional yang digelar Lembaga Penjamin Mutu Pendidikan (LPMP) Maluku, mengakui mutu dan kualitas guru ditanah air saat ini masih rendah. Dikatakannya bahwa "hasil uji kompetensi yang dilakukan selama tiga tahun terakhir menunjukan kualitas guru ditanah air saat ini masih rendah" (Ella Syafputri, 2014: www.antaranews.com).
Syahwal Gultom juga menilai buruknya Ujian Nasional (UN) pada beberapa provinsi juga sebagai salah satu indikator rendahnya kualitas guru. Banyak guru tidak memahami substansi keilmuan yang dimiliki maupun pola pembelajaran yang tidak tepat diterapkan kepada anak didik. Kepala Dinas Pendidikan DKI Jakarta, Larso Marbun menilai kompetensi guru yang masih rendah menjadi alasan bertambahnya pengangguran lulusan dari sekolah menengah kejuruan (SMK) pada tahun 2014. Dikatakannya bahwa "Kualitas lulusan SMK banyak yang tidak sesuai dengan permintaan pasar tenaga kerja saat ini, akhirnya banyak yang menganggur", (Taufik Rachman, 2014: www.republika.co.id).

Salah satu permasalahan dalam membangun pendidikan dan kebudayaan berdasarkan Renstra Kemendikbud 2015-2019 (2015, p.22) adalah kurangnya kapasitas Lembaga Pendidikan Tenaga Kependidikan (LPTK) dalam menyediakan guru berkualitas. Terbatasnya kualitas layanan pendidikan oleh LPTK berdampak belum adanya perbaikan yang signifikan pada peningkatan kualitas guru. Keterbatasan ini antara lain disebabkan oleh, (1) belum adanya reformasi LPTK secara menyeluruh untuk meningkatkan mutu penyelenggaraan pendidikan keguruan, (2) minimnya keterlibatan LPTK dalam proses perencanaan dan pengadaan guru berdasarkan analisis 
kebutuhan guru perdaerah (kabupaten dan kota), (3) belum tersedianya mekanisme penjamin kualitas calon mahasiswa yang masuk ke LPTK melalui proses seleksi berdasarkan merit system, (4) belum dikembangkannya kurikulum pelatihan guru yang responsif dengan kebutuhan aktual, dan (5) belum dilaksanakannya pendidikan profesi guru bagi mahasiswa baru melalui pola beasiswa berasrama.

Program Studi Pendidikan Teknik Mesin (PTM) Fakultas Keguruan dan IImu Pendidikan (FKIP) Universitas Palangka Raya (UPR) adalah salah satu Lembaga Pendidikan Tenaga Kependidikan (LPTK) Pendidikan Guru Sekolah Menengah Kejuruan (PGSMK) di bidang teknologi yang memiliki peran mempersiapkan mahasiswa untuk mampu mengajar di SMK bidang keahlian mesin produksi dan bidang keahlian otomotif, khususnya untuk kebutuhan guru SMK bidang keahlian mesin produksi dan bidang keahlian otomotif di Kalimantan Tengah. Program Studi PTM FKIP UPR merupakan LPTK PGSMK jenjang S-1 yang belum lama berdiri, penerimaan mahasiswa angkatan pertama pada tahun ajaran $2004 / 2005$. Visi yang diemban adalah menjadi program studi yang dapat menghasilkan sumber daya manusia bermoral Pancasila, bermutu, berkarakter, berdaya saing tinggi dengan penekanan menghasilkan guru profesional di bidang pendidikan teknik mesin. Tujuan yang ditetapkan yaitu menghasilkan lulusan/guru profesional di bidang pendidikan teknik mesin yang bermoral Pancasila, bermutu, berkarakter, dan berdaya saing tinggi.

Lulusan Program Studi Pendidikan Teknik Mesin memiliki kompetensi untuk mengemban tugas sebagai; (1) guru dibidang studi Teknik Manufaktur (Teknik Permesinan dan Teknik Mekanik Otomotif) di Sekolah Menengah Kejuruan (SMK); (2) guru keterampilan bidang Teknik Manufaktur (Teknik Permesinan dan Teknik Mekanik Otomotif) di Sekolah Menengah Atas (SMA), Madrasah Aliyah (MA), Sekolah Menengah Pertama (SMP); (3) instruktur di Lembaga-lembaga Diklat Bidang Manufaktur (Teknik Permesinan dan Teknik Mekanik Otomotif); dan (4) instruktur di Industri swasta di Bidang Manufaktur (Teknik Permesinan dan Teknik Mekanik Otomotif).

Dalam rangka memberikan layanan kepada mahasiswa untuk mencapai kompetensi, Program Studi PTM FKIP UPR selalu meningkatkan kualitas dan kenyamanan layanannya dalam mendukung proses pembelajaran. Lebih khusus untuk menghasilkan lulusan S-1 yang memiliki kompetensi di bidang kependidikan/ pengajaran, maka pihak Program Studi PTM selalu meningkatkan kualitas pelaksanaan mata kuliah PLP-II sebagai ajang bagi mahasiswa dalam latihan praktik mengajar dan mengelola kelas dengan baik sesuai dengan teori-teori yang dijabarkan dalam panduan pelaksanaan pengajaran PPL-II.
Pengenalan lapangan persekolahan (PLP-II) merupakan salah satu mata kuliah yang termasuk dalam kelompok mata kuliah profesi dalam Program Studi PTM UPR yang memiliki tujuan untuk mengembangkan kemampuan profesional mahasiswa PTM sebagai tenaga pendidik. Dengan melewati PPL mahasiswa mahasiswa di Program Studi PTM UPR dituntut menggunakan pengetahuan serta keterampilan-keterampilan mengajar yang diperoleh dari perkuliahan sesuai dengan tuntutan nyata dalam situasi kerja. Namun, pada pelaksanaannya masih banyak kendala-kendala yang dihadapi oleh mahasiswa mahasiswa saat melaksanakan proses praktik mengajar seperti penelitian yang dilakukan oleh Supatra (2013, p.240) yang menyimpukan bahwa mahasiswa PPL; (1) belum memiliki kompetensi penguasaan bidang studi secara utuh sebagai mahasiswa pemula SMK, belum mampu berperan sebagai instruktur dalam pelaksanaan pembelajaran praktikum kejuruan di SMK, (2) belum mampu menciptakan atsmosfer belajar yang kondusif dalam proses pembelajaran di SMK, (3) belum mampu melaksanakan pembelajaran sesuai prinsip-prinsip dasar pembelajaran yang mendidik, (4) belum mampu melakukan refleksi terhadap kinerjanya dalam proses pembelajaran.

Jusoh (2011, p.187) dalam penelitiaannya juga menyimpulkan bahwa pengalaman praktik mengajar oleh mahasiswa sangat tidak menyenangkan karena mereka mengalami banyak tantangan selama praktikum. Hal ini menunjukan bahwa mahasiswa praktik masih belum dilengkapi dengan keterampilan dan pengetahuan yang baik dalam mempersiapkan mereka didunia yang nyata. Mereka secara mental belum siap untuk memikul tanggung-jawab tersebut, sehingga mereka telah menciptakan suasana yang tegang untuk diri mereka sendiri. Hasil tersebut didukung oleh hasil penelitian Gujjar (2010, p.339) bahwa dari 650 mahasiswa yang telah menyelesaikan praktik mengajar ditemukan bahwa mahasiswa di Pakistan masih belum serius dalam pelaksanaan praktik mengajar dan masih banyak temuan menarik yang ditemukan dalam hal ini.

Berdasarkan beberapa uraian tersebut, sebagai mahasiswa di Program Studi PTM UPR perlu dibekali empat kompetensi dasar, yaitu kompetensi pedagogik, kompetensi kepribadian, kompetensi sosial dan kompetensi profesional. Dalam penelitian ini yang akan dikaji adalah kompetensi pedagogik, kompetensi kepribadian, kompetensi sosial dan kompetensi profesional. Penelitian ini bertujuan untuk mendeskripsikan keempat kompetensi yang dimiliki oleh mahasiswa di Program Studi PTM UPR yang sudah melakukan PLP-II. 


\section{METODE PENELITIAN}

Jenis penelitian ini adalah penelitian deskriptif yang bertujuan untuk memperoleh gambaran tentang kompetensi mahasiswa Program Studi PTM UPR berdasarkan persepsi diri sebagai calon guru.

Populasi penelitian ini adalah seluruh mahasiswa Program Studi PTM UPR yang telah melaksanakan pengenalan lapangan persekolahan (PLP-II). Teknik sampling yang digunakan adalah cluster sampling, yaitu dari semua mahasiswa hanya dipilih mahasiswa yang sudah melaksanakan PLP-II.

Teknik analisis data yang digunakan adalah analisis data statistik deskriptif. Penyajian data dilakukan dengan tabulasi data dalam bentuk tabel atau daftar dan divisualisasikan dalam diagram atau grafik statistik.

Tabel 1. Konversi Nilai Persentase ke dalam Kategori

\begin{tabular}{cc}
\hline Interval Nilai & Kategori \\
\hline $\mathbf{7 5 \%}-\mathbf{1 0 0 \%}$ & Baik \\
$\mathbf{5 0 \%}-\mathbf{7 4 , 9 9 \%}$ & Cukup Baik \\
$\mathbf{2 5 \%}-\mathbf{4 9 , 9 9 \%}$ & Kurang Baik \\
$\mathbf{0 \% - 2 4 , 9 9 \%}$ & Tidak Baik \\
\hline
\end{tabular}

\section{HASIL PENELITIAN}

Kompetensi mahasiswa mahasiswa di Program Studi PTM UPR ditinjau dari kompetensi pedagogik.
Adapun deskripsi data kompetensi mahasiswa mahasiswa di Program Studi PTM UPR disajikan pada Tabel 3. berikut ini.

Tabel 1. Rangkuman Kategori Kompetensi mahasiswa mahasiswa

\begin{tabular}{cccc}
\hline \multicolumn{1}{c}{ Persepsi } & \multicolumn{2}{c}{ Mean } & Kategori \\
\cline { 2 - 3 } Penilaian & Skor & $\%$ & \\
\hline Mahasiswa & 267,76 & 72,37 & Cukup Baik \\
(diri Sendiri) & & & \\
\hline
\end{tabular}

\section{Kompetensi Pedagogik Mahasiswa Progam Studi berdasarkan persepsi diri mendapatkan persentase Pendidikan Teknik Mesin UPR

Berdasarkan analisis deskriptif, kompetensi pedagogik mahasiswa Program Studi PTM UPR

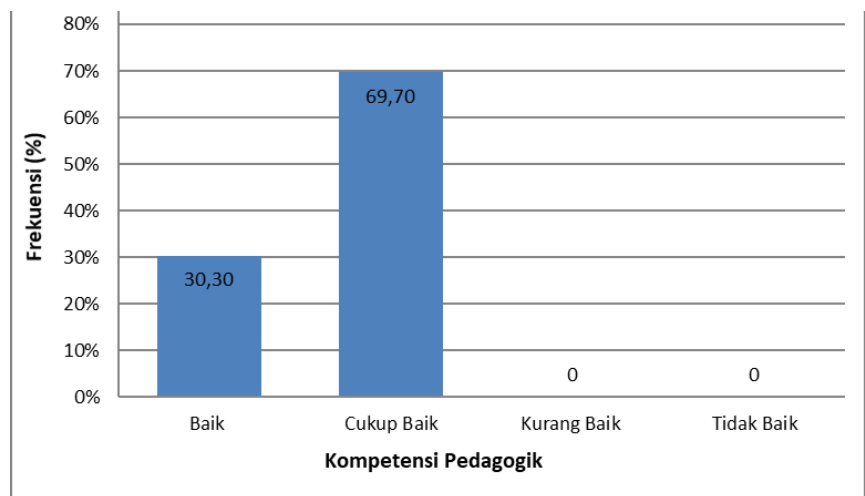

Gambar 1. Persepsi diri terhadap Kompetensi Pedagogik

Hasil Penelitian menunjukan bahwa kompetensi pedagogik mahasiswa Program Studi PTM UPR berdasarkan persepsi diri, 30,30\% mahasiswa sudah merasa baik, dan $69,70 \%$ merasa cukup baik. Hal ini menunjukan bahwa mahasiswa Program Studi PTM UPR mayoritas mempunyai presepsi bahwa kemampuan kompetensi pedagogik mereka cukup baik. 


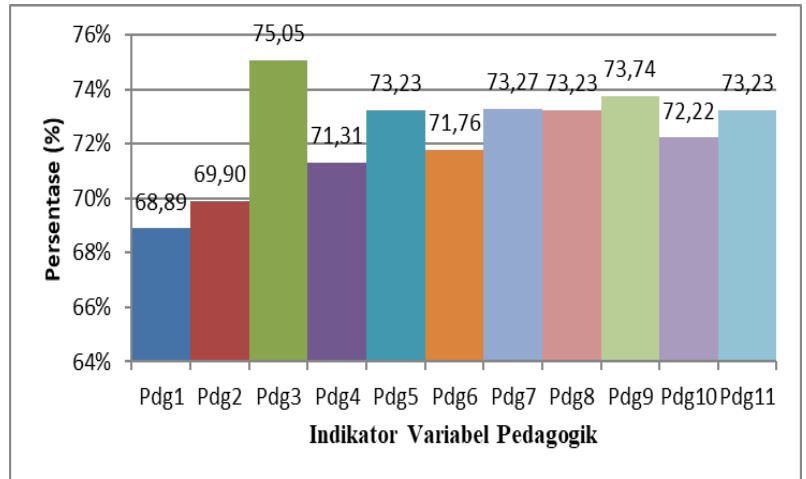

Gambar 2. Kompetensi Pedagogik berdasarkan Indikator Variabel

Berdasarkan indikator variabel kompetensi pedagogik pada indikator 1 didapat hasil perserntae $68,89 \%$ masuk dalam kategori cukup baik, indikator 2 didapat persentase $69,90 \%$ masuk dalam kategori cukup baik, indikator 3 didapat persentase $75,05 \%$ masuk dalam kategori baik, indikator 4 didapat persentase $71,31 \%$ masuk dalam kategori cukup baik, indikator 5 didapat persentase 73,23\% masuk dalam kategori cukup baik, indikator 6 didapat persentase 71,76\% masuk dalam kategori cukup baik, indikator 7 didapat persentase $73,27 \%$ masuk dalam kategori cukup baik, indikator 8 didapat persentase $73,23 \%$ masuk dalam kategori cukup baik, indikator 9 didapat persentase 73,74 masuk dalam kategori cukup baik, indikator 10 didapat persentase $72,22 \%$ masuk dalam kategori cukup baik dan indikator 11 didapat persentase 73,23 masuk dalam kategori cukup baik.

\section{Kompetensi Kepribadian Mahasiswa Program Studi PTM UPR}

Berdasarkan analisis deskriptif, kompetensi kepribadian mahasiswa Program Studi PTM UPR berdasarkan persepsi diri mendapatkan persentase skor rata-rata adalah $77,71 \%$.

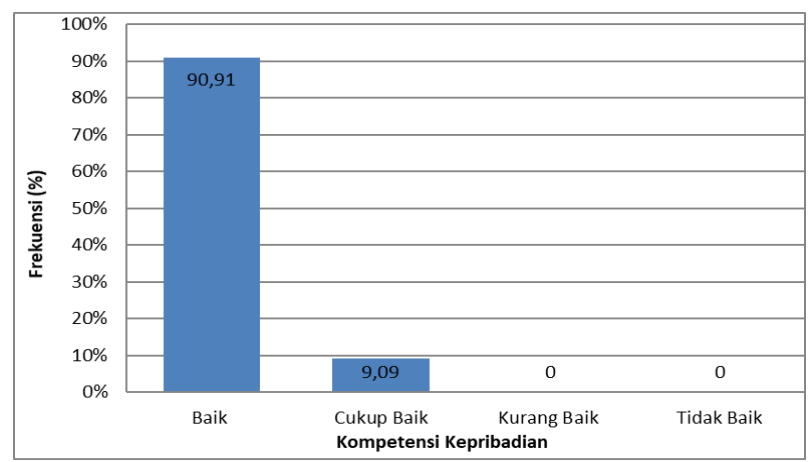

Gambar 3. Persepsi diri terhadap Kompetensi Kepribadian

Hasil Penelitian menunjukan bahwa kompetensi kepribadian mahasiswa Program Studi PTM UPR berdasarkan persepsi diri, 90,91\% mahasiswa sudah merasa baik, dan 9,09\% merasa cukup baik. Hal ini menunjukan bahwa mahasiswa Program Studi PTM UPR mayoritas mempunyai presepsi bahwa kompetensi kepribadian mereka baik.

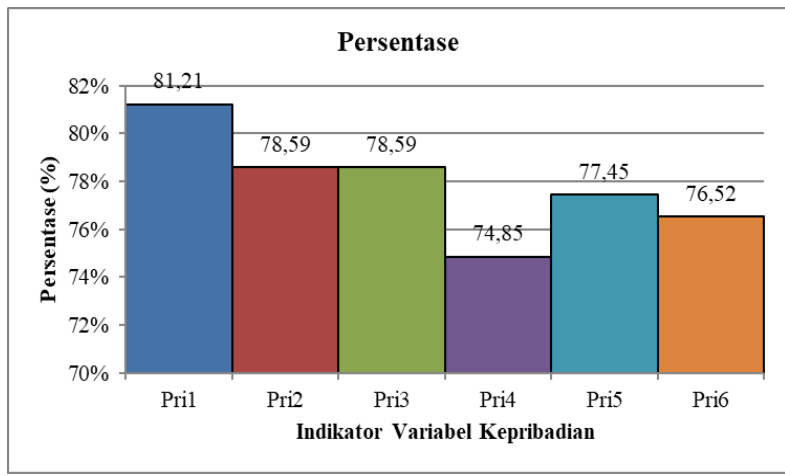

Gambar 4. Kompetensi Kepribadian berdasarkan Indikator Variabel 
Berdasarkan indikator variabel kompetensi kepribadian mahasiswa Program Studi PTM UPR pada indikator 1 diperoleh persentase 81,21\% masuk dalam kategori baik, indikator 2 diperoleh persentase 78,59 masuk dalam kategori baik, indikator 3 diperoleh persentase 78,59 masuk dalam kategori baik, indikator 4 diperoleh persentase 74,85 masuk dalam kategori cukup baik, indikator 5 diperoleh persentase $77,45 \%$ masuk dalam kategori baik, dan indikator 6 diperoleh persentase 76,52 masuk dalam kategori baik.

\section{Kompetensi Sosial Mahasiswa Program Studi PTM} UPR

Analisis deskriptif kompetensi sosial mahasiswa Program Studi PTM UPR berdasarkan persepsi diri mendapatkan persentase skor rata-rata adalah $77,71 \%$.

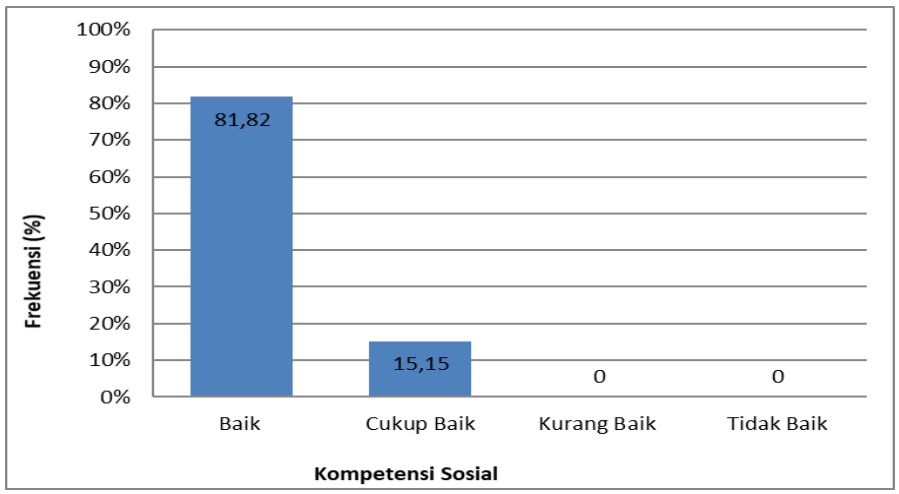

Gambar 5. Persepsi diri terhadap Kompetensi Sosial

Kompetensi sosial mahasiswa Program Studi PTM UPR berdasarkan persepsi diri diperoleh persentase $81,82 \%$ mahasiswa sudah merasa baik, dan 15,15\% merasa cukup baik. Hal ini menunjukan bahwa mahasiswa Program Studi PTM UPR mayoritas mempunyai presepsi bahwa kompetensi sosial mereka baik.

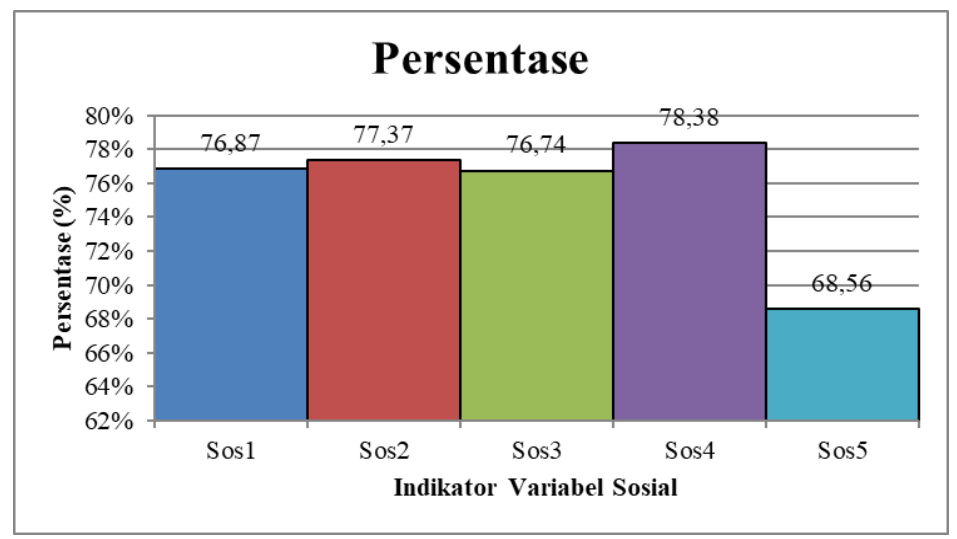

Gambar 6. Kompetensi Sosial berdasarkan Indikator Variabel

Berdasarkan indikator variabel kompetensi sosial mahasiswa Program Studi PTM UPR pada indikator 1 diperoleh persentase $76,87 \%$ masuk dalam kategori baik, indikator 2 diperoleh persentase 77,37\% masuk dalam kategori baik, indikator 3 diperoleh persentase $76,74 \%$ masuk dalam kategori baik, indikator 4 diperoleh persentase $78,38 \%$ masuk dalam kategori baik dan indikator 5 diperoleh persentase 68,56\% masuk dalam kategori cukup baik.

\section{Kompetensi Profesional Mahasiswa Program Studi PTM UPR}

Analisis deskriptif kompetensi profesional mahasiswa Program Studi PTM UPR berdasarkan persepsi diri mendapatkan persentase skor rata-rata adalah $74,63 \%$. 


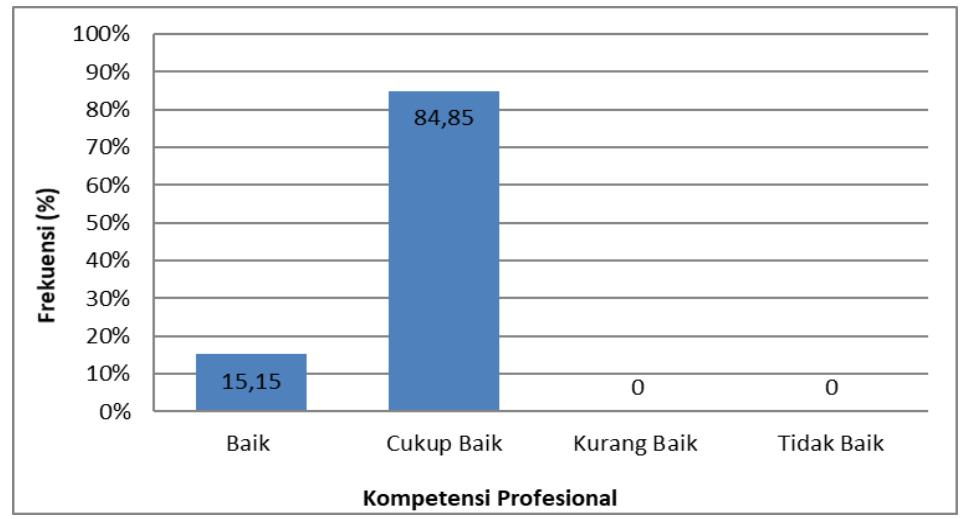

Gambar 7. Persepsi diri terhadap Kompetensi Profesional

Kompetensi profesional mahasiswa Program Studi PTM UPR berdasarkan persepsi diri diperoleh persentase $15,15 \%$ mahasiswa sudah merasa baik, dan $84,85 \%$ merasa cukup baik terhadap kompetensi professional mereka. Hal ini menunjukan bahwa mahasiswa Program Studi PTM UPR mayoritas mempunyai presepsi bahwa kompetensi profesional mereka cukup baik.

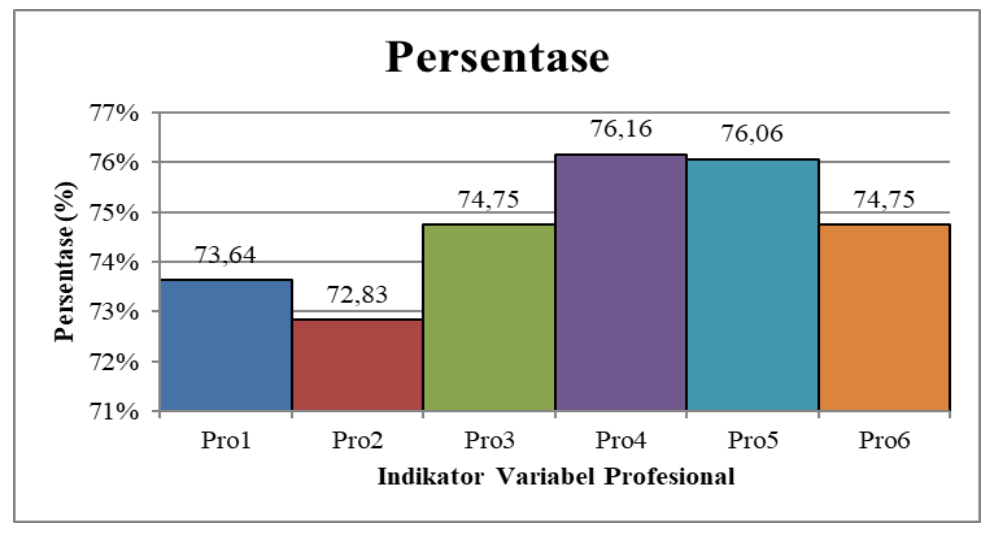

Gambar 8. Kompetensi Profesional berdasarkan Indikator Variabel

Berdasarkan indikator variabel kompetensi profesional mahasiswa Program Studi PTM UPR pada indikator 1 diperoleh persentase 73,64\% masuk dalam kategori cukup baik, indikator 2 diperoleh persentase $72,83 \%$ masuk dalam kategori cukup baik, indikator 3 diperoleh persentase $74,75 \%$ masuk dalam kategori cukup baik, indikator 4 diperoleh persentase 76,16\% masuk dalam kategori baik, indikator 5 diperoleh persentase $76,06 \%$ masuk dalam kategori baik dan indikator 6 diperoleh persentase 74,75 masuk dalam kategori cukup baik.

\section{KESIMPULAN}

Berdasarkan data yang telah dianalisis maka didapat disimpulkan bahwa kompetensi mahasiswa di Program Studi PTM UPR berdasarkan perserpsi diri yaitu berdasarkan penilaian diri adalah cukup baik. Secara rinci dapat dijelaskan, yaitu: (1) Kompetensi pedagogik yang dimiliki mahasiswa mayoritas berada pada kategori cukup baik, yaitu pada indikator mampu mengidentifikasikan potensi peserta didik, menguasai karakteristik potensi peserta didik, menguasai cara belajar peserta didik, mengenal sikap dan perilaku peserta didik, merencanakan/merancang pembelajaran, enguasai pendekatan, metode dan media pembelajaran, melaksanakan pembelajaran, mengenal prinsip dan prosedur proses penilaian, merencanakan dan melaksanakan proses penilaian dan hasil belajar peserta didik, dan memanfaatkan hasil penilaian. (2) Kompetensi kepribadian yang dimiliki mahasiswa mayoritas berada pada kategori baik, yaitu pada indikator menghargai perbedaan, bertindak sesuai norma, menampilkan pribadi yang disiplin, jujur dan berakhlak mulia, menampilkan diri yang mantap, dewasa, dan berwibawa, menunjukan etos kerja, dan menjunjung tinggi kode etik profesi guru. (3) Kompetensi sosial yang dimiliki mahasiswa mayoritas berada pada kategori baik, yaitu pada indikator mampu bertindak objektif dan tidak diskriminatif, mampu berkomunikasi secara efektif, empatik dan santun, mampu beradaptasi ditempat mengajar, dan mampu bekerja sama. (4) Kompetensi profesional yang dimiliki mahasiswa mayoritas berada pada kategori baik, yaitu pada indikator menguasai bidang studi pendidikan 
teknik mesin, mengaitkan dan mengaplikasikan bidang studi pendidikan teknik mesin, memanfaatkan teknologi informasi dan komunikasi untuk mengembangkan materi dan mengelola lab/bengkel sekolah.

\section{DAFTAR PUSTAKA}

Depdiknas, (2005). Undang-Undang Republik Indonesia Nomor 14, Tahun 2005, tentang Guru dan Dosen.

Ella Syafputri. (27 September 2013). Kemdikbud akui kualitas guru masih rendah. Ambon (ANTARA News). Diakses tanggal 19 Februari 2015 dari http://www.antaranews.com/berita/397722/kemdi kbud-akui-kualitas-guru-masih-rendah.

Gujjar, A.A., Naoreen, B., Saifi, S., et al. (2010). Teaching practice: problems and issues in Pakistan. International Online Journal of Educational Sciences, 2 (2), 339-361.

Jusoh, Z. (2013). Teaching practicum: student teachers' perspectives, paper presented at the FLLT 2013 conference downloaded dari litu.tu.ac.th/FLLT2013/ www.fllt2013.org/private_folder/.../865.pdf.

Kemendikbud, (2015). Rencana strategis kementrian pendidikan dan kebudayaan 2015-2019. Jakarta.

Supatra, I.M. (2013). Relevansi kurikulum program studi pendidikan teknik mesin FKIP Universitas Palangka Raya dengan kompetensi guru pemula SMK. Tesis magister, tidak diterbitkan, Universitas Negeri Yogyakarta, Yogyakarta.

Taufik Rachman. (17 November 2014). Kompetensi rendah jadi penyebab pengangguran SMK meningkat. Republika.co.id. diakses tanggal 19 februari 2015 dari http://www.republika. co.id/berita/pendidikan/eduaction/14/11/17/nf6id 6-kompetensi-rendah-jadi-penyebabpengangguran-smk-meningkat.

Umami, D.R. (2014). Pengaruh kompetensi pedagogik dan motivasi kerja guru terhadap prestasi belajar siswa dalam ujian nasional (un) di sma negeri se kota mojokerto. Jurnal Inspirasi Manajemen Pendidikan, 3 (3), 81-88. 